Original Paper http://ajol.info/index.php/ijbcs http://indexmedicus.afro.who.int

\title{
Prevalence and intensity of gill monogenean parasites of Tilapia guineensis (Bleeker, 1862) in man-made Lake Ayamé 2, Côte d'Ivoire according to season, host size and sex
}

\author{
Yedehi Euphrasie ADOU*, Kassi Georges BLAHOUA, Tanoh Marius KAMELAN and \\ Valentin N'DOUBA \\ Department of Biological Sciences, Laboratory of Hydrobiology, Faculty of Science and Technology, \\ University of Félix Houphouët Boigny, Abidjan, 22 P.O. Box 582 Abidjan 22, Côte d'Ivoire. \\ ${ }^{*}$ Corresponding author; E-mail: adoueuphra@yahoo.fr; Tel: + 22508362428 / 01064370
}

\begin{abstract}
The study of the gills of 361 Tilapia guineensis was conducted from July 2015 to June 2016 to determine the effect of seasonal changes, host size and sex on the incidence of monogenean parasites infection. Standard methods of parasitological examination were used for identification of monogenean species. Eleven species were identified. Seasonal changes in the rates of infection for all the monogenean species were found. The highest values of prevalence and mean intensity were observed in the rainy seasons and the lowest values in the long dry season, particularly. The parasite load of all monogenean except of Cichlidogyrus kouassii increased with the size of the fish. It also showed that the sex of the host influenced the parasites burden. The intensities of infection of C. vexus, C. ergensis, C. cubitus were higher in female fish than in male. Moreover, $C$. digitatus and $C$. dossoui were more concentrated in male than female whereas there was not a difference in infection of C. anthemocolpos, C. arthracanthus, C. yanni, C. lagoonaris, C. louipaysani and C. kouassii based on the sex of Tilapia guineensis. This could enable the use of appropriate methods to fight against these pathogens, especially in intensive fish farming.

(C) 2017 International Formulae Group. All rights reserved.
\end{abstract}

Keywords: Monogeneans, Tilapia guineensis, population dynamics, Lake Ayamé 2.

\section{INTRODUCTION}

The growing demand for food sources, particularly protein, has made aquaculture to be one of the fastest growing food sectors in the world. Among the variety of freshwater fish, Tilapia has become one of the major cultured fish in the world after carp fish (ElSayed, 2006; Wang and Lu, 2015). Tilapia guineensis (Bleeker, 1862) is a euryhaline species found in estuaries and lagoons of West Africa (Philippart and Ruwet, 1982). This species has gained an increasing interest for aquaculture purposes, particularly in the estuaries and extensive lagoon systems which constitute its natural range (Akinwumi, 2003; Akinrotimi, 2006; Toko et al., 2010). This species contributes significantly to the economy and health benefits of the fishers in the riverine areas where other animal sources of proteins are beyond the reach of the poor populace. Health benefits of fish and fishery products are increasingly being recognized (Tammy, 2002), placing a high demand on fishery products. According to Baidoo et al. 
(2015), among numerous factors that affect the production of Cichlids are parasitic infections and diseases.

Monogeneans are parasites mostly found on the gills and skin of freshwater and saltwater fish. They invade the rectal cavity, ureter, body cavity, nostrils, intestine, stomach and even the vascular system (Pariselle and Euzet, 1998; Whittington et al., 2000). Their development cycle is direct (no host intermediary) and has a larva with cilia often swimming (oncomiridia), which is an only free stage. There is an equilibrium between host and parasite and monogenean parasites cause few obvious problems in nature. However, these parasites can reach very significant prevalence in captivity, such that the number of affected fish and the parasite load per host are both increased, which makes the disease evident and severe (Aloo, 2002 ; Buchmann and LindenstrØm, 2002). Tilapia guineensis, which is economically and ecologically important as food fish and for aquaculture could face such problem. This requires a good taxonomic and biological knowledge of pathogenic agents. For Sures and Streit (2001), knowledge of fish parasites is of particular interest in relation not only to fish health but also to understanding ecological problems. Parasitological knowledge has been useful in the development of the aquaculture industry in many parts on the words through the production of vaccines, antibiotics and introduction of bio-security measures to minimize the mass fish mortalities and boots global food fish (Lom and Dykova, 1992).

In Côte d'Ivoire, few studies (Pariselle and Euzet, 2009) have been conducted on monogenean parasites of Tilapia guineensis. However, when all published information is considered, the data on parasitic monogenean of this fish species are still insufficient. Moreover, none of the previous studies have focused on the frequency of parasitic infection and its variation due to season, host size and sex. Therefore, the aim of the present study was mainly to fill these gaps in the knowledge on the parasitic monogenean of Tilapia guineensis in man-made Lake Ayamé 2.

\section{MATERIALS AND METHODS \\ Fish sampling}

A total of 361 Tilapia guineensis specimens were caught from Lake Ayamé 2 between July 2015 and June 2016. This Lake is located in southeast of Côte d'Ivoire ( $5^{\circ} 34^{\prime}$ $5^{\circ} 37^{\prime} \mathrm{N}$ and $3^{\circ} 09^{\prime}-3^{\circ} 10^{\prime} \mathrm{W}$ ) and is the one of hydroelectric dam in the country (Figure 1). Fish samples were captured using gill-nets and commercial fish landings and held workshop with the local fishermen. Once caught, the fish were immediately identified according to the keys given by Teugels and Thys van den Audenaerde (2003). The standard length (SL) of each specimen was measured to the nearest $1 \mathrm{~mm}$ on a measuring board and its sex was determined. Fish whose, standard length (LS) ranged from 140 to 200 $\mathrm{mm}$ have been placed in six class sizes which are class A $(140 \leq \mathrm{SL}<150)$, class B $(150 \leq$ $\mathrm{SL}<160)$, class $\mathrm{C}(160 \leq \mathrm{SL}<170)$, classes $\mathrm{D}(170 \leq \mathrm{SL}<180)$, class E $(180 \leq \mathrm{SL}<190)$ and class $\mathrm{F}(190 \leq \mathrm{SL} \leq 200)$.

In the laboratory, the gills from each side were dissected and were placed in various Petri dishes. Monogeneans were collected and mounted on a slide into a drop of ammonium picrate-glycerine mixture (Malmberg, 1957). The identification of the parasite species was carried out under the light microscope, based on the shape and/or size of the sclerotised parts of their haptoral and copulatory complexes as described by Pariselle and Euzet (2009).

\section{Parasitological analysis}

The data of prevalence (proportion of the infected population) and mean intensity (mean number of parasites of infected hosts) for all monogenean joined were calculated as suggested by Bush et al. (1997). Based on the prevalence, species was considered as common (core) if the prevalence is greater than 50\%, intermediate (secondary) if prevalence is between 10 and $50 \%$ and rare (satellite) if prevalence is less than $10 \%$ 
(Valtonen et al., 1997). The mean intensity (MI) was high if $\mathrm{MI}$ is greater than 100, medium if MI ranged between 50 and 100, low if MI ranged between 10 and 50; and very low if MI is less than 10 as described by Bilong Bilong and Njiné (1998).

\section{Statistical analysis}

The difference in parasite prevalence was tested by using Chi-square $\left(\mathrm{X}^{2}\right)$. The Kruskal Wallis (K) was used to test the differences in intensity of infestation between seasons and host size classes. Following a significant main effect, Mann-Whitney (U) analysis was used to test pair wise comparison. Effect of host sex on infestation intensity of each parasite species was examined using Mann-Whitney's test. All steps of this method were computed using STATISTICA 7.1 software.

\section{RESULTS}

Eleven species of monogeneans were identified on the gills of the fish: Cichlidogyrus vexus, C. ergensis, C. cubitus, C. anthemocolpos, C. arthracanthus, C. yanni, C. digitatus, C. dossoui, C. lagoonaris, C. louipaysani and $C$. kouassii. The sex ratio $(\mathrm{M} / \mathrm{F})$ of the host population was 0.9 .

\section{Seasonal dynamics of the Monogenean species}

Cichlidogyrus vexus / C. ergensis / C. cubitus

Prevalence and mean intensity of

Cichlidogyus vexus are shown in table 1 . The lowest value of prevalence (92\%) was registered in the small dry season and the highest $(96.15 \%)$ in the small rainy season. The temporal variations of the occurrence were not statistically significant at 5\% $\left(\mathrm{X}^{2}=\right.$ 1.05 , df $=3, \mathrm{p}=0.78>0.05)$. The mean intensity ranged between $6.87 \pm 0.7$ in the long dry season and $33.28 \pm 8$ in the small rainy season. A significant difference of seasonal infestation was found (Kruskal Wallis, MannWhitney, $\mathrm{p}<0.05$ ) (Table 1).

With regard to Cichlidogyrus ergensis, the prevalence and mean intensity ranged from 78.17 to $88.46 \%$ and $6.72 \pm 0.9$ to
$20.78 \pm 7.6$, respectively between the seasons, with the highest values recorded in the small rainy season and the lowest one in the long dry season. No significant difference was found in prevalence among four seasons $\left(\mathrm{X}^{2}=\right.$ 2.22 , df $=3, p=0.52>0.05)$ whereas the intensity of infestation varied significantly (Kruskal Wallis, $\mathrm{p}<0.05$ ) and changed from one season to another (Mann-Whitney, p < $0.05)$, except from the small dry to the long dry seasons and from the small rainy to the long rainy seasons (Table 1).

The seasonal prevalence of C. cubitus varied from 67.31 to $75-54 \%$. It was higher in the long rainy season and lower in the small rainy season. There was no significant difference between prevalence of seasons $\left(\mathrm{X}^{2}\right.$ $=1.56$, df $=3, \mathrm{p}=0.6>0.05)$. The mean intensity of $C$. cubitus was higher (19.54 \pm 5.2$)$ on the fish in the small rainy season and lower $(6.56 \pm 0.6)$ in the long dry season. The statistical analyse revealed that the infestation of this host by this parasite differed significantly among seasons (Kruskal Wallis, Mann-Whitney, $\mathrm{p}<0.05$ ).

Cichlidogyrus anthemocolpos / $C$. arthracanthus / C. yanni

The number of infected fish of Cichlidogyrus anthelmocolpos ranged from $65.47-78.85 \%$, with the lowest values recorded in the long rainy season and the highest in the small rainy season. Statically, no difference was highlighted during seasons of the year $\left(\mathrm{X}^{2}=5.08\right.$, df $=3, \mathrm{p}=0.16>$ $0.05)$. The highest mean intensity $(17.88 \pm 2.2)$ was found in the small rainy season and the lowest mean intensity $(5.59 \pm 0.3)$ in the long dry season. Kruskal Wallis test analysis applied of the data showed statistically significant differences in the intensity of parasites between seasons $(p<0.05)$ and varied from one season to another (MannWhitney, $\mathrm{p}<0.05$ ), except from the small to the long rainy seasons (Table 1).

The prevalence and the intensity of infestation of Cichlidogyrus arthracanthus varied from $35-48.20 \%$ and $5.61 \pm 2$ to $2.02 \pm 1$ respectively, during the seasons. The highest rate of infestation was registered in the long 
rainy season and the lowest one in the long dry season. The Chi-square $\left(\mathrm{X}^{2}\right)$ applied to the temporal variations of the rate of infestation showed that these values were not statistically significant at $5 \%\left(\mathrm{X}^{2}=4.68, \mathrm{df}=3, \mathrm{p}=0.2>\right.$ $0.05)$.The highest value of mean intensity was obtained in the small rainy season and the lowest one in the long dry season. A significant difference of seasonal infestation was found (Kruskal Wallis, $\mathrm{p}<0.05$ ) and changed from one season to another (MannWhitney, $\mathrm{p}<0.05$ ), except from the small to the long dry seasons (Table 1).

Cichlidogyrus yanni was absent during the small dry season. Significant differences were noted among seasonal rate of infestation $\left(\mathrm{X}^{2}=21.73, \mathrm{df}=3, \mathrm{p}=0.00<0.05\right)$ with the highest value $(23.08 \%)$ in the small rainy season. The highest value of the mean intensity was $2 \pm 1$ and was recorded in the long dry season. The intensity of infestation also varied significantly during the seasons (Kruskal Wallis, $\mathrm{p}<0.05$ ) and changed from one season to another (Mann-Whitney, $\mathrm{p}<$ $0.05)$, except from the small to the long rainy seasons and from the long dry to long rainy seasons (Table 1).

\section{Cichlidogyrus digitatus / C. dossoui / C. lagoonaris}

The rate of infestation of Cichlidogyrus digitatus ranged from $76.26 \%$ in the long rainy season to $8 \%$ in the small dry season. Significant difference was found in prevalence of infestation between seasons $\left(\mathrm{X}^{2}\right.$ $=97.46, \mathrm{df}=3, \mathrm{p}=0.00<0.05)$. The minimum level of mean intensity $(1.43 \pm 1)$ was observed in the long dry season and the maximum level $(3.37 \pm 1)$ in the small rainy season. Kruskal Wallis test was significant between seasons $(\mathrm{p}<0.05)$ and the intensity of infestation changed from one season to another (Mann-Whitney, $\mathrm{p}<0.05$ ), except from the long dry to the long rainy seasons (Table 1).

For Cichlidogyrus dossoui, the minimum prevalence of infestation $(4 \%)$ was observed in the small dry season and the maximum $(71.22 \%)$ in the long rainy season. There was a significant difference among prevalence of seasons $\left(X^{2}=77.57, d f=3, p=\right.$ $0.00<0.05)$. Mean intensity values ranged from $1.01 \pm 0.05$ to $3.75 \pm 1$. Statistically, significant difference was recorded in the intensity of parasites between seasons (Kruskal Wallis, Mann-Whitney, $\mathrm{p}<0.05$ ) (Table 1).

Cichlidogyrus lagoonaris was not detected in the small dry season. The maximum prevalence (11.51\%) of this parasite was found in the long rainy season and mean intensity (3.33 \pm 0.5 .) in the long dry season. During the year, prevalence and intensity of infestation differed statistically between sampling seasons $\left(X^{2}=13.08, d f=3\right.$, $\mathrm{p}=0.00<0.05$, Kruskal Wallis, MannWhitney $\mathrm{p}<0.05$ ) (Table 1).

\section{Cichlidogyrus louipaysani / C. kouassii}

The monogenean Cichlidogyrus louipaysani was observed in each fish examined in the long rainy season, with a maximum prevalence $(30.94 \%)$. The minimum rate of infestation (4\%) was obtained in the small dry season. Seasonal variation of prevalence differed significantly $\left(\mathrm{X}^{2}=14.85, \mathrm{df}=3, \mathrm{p}=0.00<0.05\right)$. Mean intensity values ranged from $1.2 \pm 0.1$ in the small dry season to $2.43 \pm 0.1$ in the small rainy season. There were significant differences between seasons (Kruskal Wallis $\mathrm{p}$ $<0.05)$ and the intensity of infestation changed from one season to another (MannWhitney, $\mathrm{p}<0.05$ ), except from the small rainy to the long rainy seasons (Table 1).

Seasonal prevalence of Cichlidogyrus kouassii varied between 0 and $15.38 \%$, being the highest in the long rainy season and the lowest in the small dry season. The values of mean intensity ranged between 0 and $3 \pm 1.5$, respectively. There were significant differences in the prevalences and the intensity of infestation of seasons $\left(X^{2}=45.84\right.$, $\mathrm{df}=3, \mathrm{p}=0.00<0.05$; Kruskal Wallis $\mathrm{p}<$ $0.05)$ and varied from season to another (Mann-Whitney, $\mathrm{p}<0.05$ ), except from to the small to the long rainy seasons and from the long dry to the long rainy seasons (Table 1). 
Occurrence of monogenean species according to length classes of the host fish Cichlidogyrus vexus / C. ergensis / C. cubitus The maximum prevalence $(100 \%)$ of Cichlidogyrus vexus and mean intensity $(48.59 \pm 3)$ were found in the classes $\mathrm{E}$ and $\mathrm{F}$, respectively. The minimum prevalence $(87.69 \%)$ and mean intensity $(5.63 \pm 1.64)$ were recorded in the class A. Statistical tests showed that there was no significant difference in the prevalence according to the size class $\left(X^{2}=10.72, \mathrm{df}=5, \mathrm{p}=0.057>\right.$ $0.05)$. However, a significant difference in the intensity of infestation was found (Kruskal Wallis $\mathrm{p}<0.05$ ) (Table 2).

As for C. ergensis, the highest prevalence $(100 \%)$ was registered for class $\mathrm{F}$ and the lowest $(58.46 \%)$ for class $\mathrm{A}$. The values of mean intensity varied from $7.21 \pm 3.12$ to $24.22 \pm 5.13$. Prevalence and intensity of infestation were significantly different $\left(X^{2}=60.80, d f=5, p=0.00<0.05\right.$, all comparisons, $\mathrm{p}<0.05$ ) (Table 2).

The minimum and maximum prevalence $(49.23 \%$ and $88.33 \%)$ of $C$. cubitus were observed for classes $\mathrm{A}$ and $\mathrm{E}$, respectively. The Chi-square test indicated statistically significant difference $\left(X^{2}=49.04\right.$, $\mathrm{df}=5, \mathrm{p}=0.00<0.05)$. The mean intensity increased progressively with host size and reached the highest values $(20.80 \pm 4.3)$ in the class F. Globally, the difference was statistically significant (Kruskal Wallis $\mathrm{p}<$ 0.05) (Table 2).

\section{Cichlidogyrus anthemocolpos / C. arthracanthus / C. yanni}

The lowest prevalence $(38.48 \%)$ of Cichlidogyrus anthemocolpos was recorded in the fish of the class A and the highest values $(91.67 \%)$ in the class $\mathrm{E}$. The values of mean intensity were lower $(5.31 \pm 1.5)$ in the class $\mathrm{C}$ and higher $(18.50 \pm 3.5)$ in the class $F$. The rate of infestation was significantly increased with length $\left(X^{2}=67.93, d f=5, p=0.00<0.05\right.$, Kruskal Wallis $\mathrm{p}<0.05$ ) (Table 2).

For C. arthracanthus, the prevalence and the mean intensity were maximum $(84 \%$ and $5.90 \pm 1$, respectively) in the class $\mathrm{F}$ and minimum ( $16.92 \%$ and $1.82 \pm 1$, respectively) in the class A. Differences were significant at $5 \%$ among the size classes $(\chi 2=67.71, \mathrm{df}=5$, $\mathrm{p}=0.00<0.05$, Kruskal Wallis $\mathrm{p}<0.05$ ) (Table 2).

Cichlidogyrus yanni was absent in the fish of the size class $B$. The highest prevalence (28\%) was found in the class $\mathrm{F}$. The differences in the prevalence between the classes were significant $\left(X^{2}=41.83, \mathrm{df}=3, \mathrm{p}\right.$ $=0.00<0.05)$. The highest mean intensity $(2.14 \pm 1.3)$ was registered in the class $F$ (Kruskal Wallis $\mathrm{p}<0.05$ ) (Table 2).

Cichlidogyrus digitatus / C. dossoni / C. lagoonaris

The highest prevalence (88\%) of Cichlidogyrus digitatus was registered for class F and the lowest (27.69\%) for class A. A significant difference was found according to the size classes $\left(X^{2}=68, d f=5, p=0.00<\right.$ $0.05)$. The values of mean intensity were lower $(1.14 \pm 0.1)$ in the class $\mathrm{A}$ and higher $(2.90 \pm 0.3)$ in the class $F$. The difference of intensity of infestation between size class was statistically significant (Kruskal Wallis $\mathrm{p}<$ 0.05) (Table 2).

For Cichlidogyrus dossoui, the highest prevalence and mean intensity were recorded for class $\mathrm{F}$ with $92 \%$ and $3.10 \pm 2$, respectively. Class A possesses the lowest prevalence $(15.38 \%)$ and mean intensity (1.21 \pm 0.7$)$. Differences were significant at $5 \%$ between the size classes $\left(\mathrm{X}^{2} \square \square 106.07\right.$, df $\square \square 5, p=$ $0.00<0.05$, Kruskal Wallis $\mathrm{p}<0.05$ ) (Table 2).

Cichlidogyrus lagoonaris was absent in fish on the size classes A and B. The highest prevalence $(18 \%)$ was found in the class $\mathrm{F}$ and the lowest $(0 \%)$ in the classes $\mathrm{A}$ and $\mathrm{B}$. The values of mean intensity varied from 0 to $2.86 \pm 1.6$. Statistical tests showed significant difference in rates of infestation $\left(X^{2}=26.59, \mathrm{df}=5, \mathrm{p}=0.00<0.05\right.$, Kruskal Wallis $\mathrm{p}<0.05$ ) (Table 2).

\section{Cichlidogyrus louipaysani / C. kouassii}

Cichlidogyrus louipaysani was not present in fish on size class A. The highest prevalence $(42 \%)$ was recorded for class $\mathrm{F}$ and the lowest $(0 \%)$ for class $\mathrm{A}$. The values of mean intensity were lower (0) in the class A 
and higher $(2.33 \pm 0.8)$ in class F. Prevalence and intensity of infestation were significantly different $\left(X^{2}=37.47, d f=5, p=0.00<0.05\right)$ (Table 2).

The maximum prevalence $(10 \%)$ of Cichlidogyrus kouassii was recorded in the class $\mathrm{F}$ and the minimum (1.59\%) in the class B. Statistical tests showed significant difference in prevalence according to the size classes $\left(\mathrm{X}^{2}=5.05, \mathrm{df}=5, \mathrm{p}=0.4>0.05\right)$. Mean intensity ranged from $2 \pm 0.4$ in the class A to $2.67 \pm 1.4$ in the class F. No significant difference was found in the intensity of infestation according to the size classes (Kruskal Wallis $\mathrm{p}>0.05$ ) (Table 2).

\section{Occurrence of monogenean species on fish hosts in relation to host sex}

Cichlidogyrus vexus / C. ergensis / C. cubitus

Cichlidogyrus vexus was present in $97.80 \%$ with a mean intensity of $24.48 \pm 2.7$ of female Tilapia guineensis and $90.17 \%$ with a mean intensity of $13.32 \pm 1.61$ of male host. Prevalence values were not significant at $5 \%$ $\left(X^{2}=9.75, \mathrm{df}=1, \mathrm{p}=0.06>0.05\right)$. In contrast, significantly higher intensity of infestation was observed in females than in males (Mann-Whitney $\mathrm{p}<0.05$ ) (Table 3).

The rate of infestation by Cichlidogyrus ergensis was $81.50 \%$ for male fish and $82.44 \%$ for female fish. The Chisquare test $\left(\mathrm{X}^{2}\right)$ applied at the occurrence of this parasite showed that these values were not statistically significant $\left(X^{2}=0.05, \mathrm{df}=1, \mathrm{p}=\right.$ $0.8>0.05$ ). Intensity of infestation was 9.14 \pm 0.2 for male and $20.35 \pm 0.1$ for female. The difference between host sex was statistically significant (Mann-Whitney $\mathrm{p}<0.05$ ) (Table $3)$.

For Cichlidogyrus cubitus, prevalence and mean intensity values were $71.09 \%$ and $9.52 \pm 0.9$ for male and $76.06 \%$ and $14.14 \pm 2.5$ for female fish, respectively. Differences were not significant between the male and female $\left(\mathrm{X}^{2}=1.15, \mathrm{df}=1, \mathrm{p}=0.3>0.05\right)$. However, Mann-Whitney test analysis showed that the females were more parasitized than males $(\mathrm{p}=$ $0.03<0.05$ ) (Table 3 ).
Cichlidogyrus anthemocolpos, $\quad$. arthracanthus / C. yanni

Prevalence and mean intensity of Cichlidogyrus anthemocolpos were $73.40 \%$ and $10.97 \pm 1$ for female and $70.52 \%$ and $11.18 \pm 0.6$ for male, respectively. Statistical tests showed no significant difference in rates of infestation between host sex $\left(\mathrm{X}^{2}=0.37 \mathrm{df}\right.$ $=1, \mathrm{p}=0.54>0.05$; Mann-Whitney $\mathrm{p}>0.05$ ) (Table 3).

As for Cichlidogyrus arthracanthus, it was present in $45.08 \%$ of male host and $39.89 \%$ of female host. The intensities of infestation were $4.10 \pm 0.5$ in the male and $3.89 \pm 0.6$ in the female. The prevalence and the intensity of infestation were not significantly different $\left(X^{2}=0.99, \mathrm{df}=1, \mathrm{p}=\right.$ $0.3>0.05$; Mann-Whitney $\mathrm{p}>0.05$ ) (Table $3)$.

For Cichlidogyrus yanni, it was present in $11.70 \%$ of female host and $6.93 \%$ of male host. The mean intensity was $1.59 \pm 0.02$ in the female and $1.75 \pm 0.01$ in the male. Statistical tests indicated no significant difference in rates of infestation between host sex $\left(\mathrm{X}^{2}=\right.$ $2.40, \mathrm{df}=1, \mathrm{p}=0.12>0.05$; Mann-Whitney $\mathrm{p}$ $>0.05$ ) (Table 3).

\section{Cichlidogyrus digitatus / C. dossoui / C. lagoonaris}

The rate of infestation of Cichlidogyrus digitatus was $54.33 \%$ of male and $46.80 \%$ of female host. No significant difference was observed according to host sex $\left(\mathrm{X}^{2}=2.04\right.$, df $=1, \mathrm{p}=0.15>0.05)$. Mean intensity values were $2.64 \pm 0.8$ for male and $1.04 \pm 0.1$ for female. A significantly higher intensity of infestation was observed in male than female (Mann-Whitney $\mathrm{p}>0.05$ ) (Table 3).

As for Cichlidogyrus dossoui, the prevalence and the mean intensity were $46.27 \%$ and $1.17 \pm 0.03$ for female and $52.60 \%$ and $2.5 \pm 1.9$ for male, respectively. The Chisquare test $(\chi 2)$ applied at the occurrence of this parasite showed that these values were not statistically significant $\left(X^{2}=1.44, \mathrm{df}=1, \mathrm{p}=\right.$ $0.2>0.05$ ). In contrast, a significantly higher intensity of infestation was observed in male 
than female (Mann-Whitney $\mathrm{p}>0.05)$ (Table $3)$.

The number of infected fish of Cichlidogyrus lagoonaris was $6.91 \%$ with a mean intensity of $2.11 \pm 0.5$ for male and $5.20 \%$ with a mean intensity of $2.84 \pm 1.6$ for female host. No significant difference was observed according to host sex $\left(\mathrm{X}^{2}=0.46\right.$, df $=1, \mathrm{p}=0.5>0.05$; Mann-Whitney $\mathrm{p}>0.05$ ) (Table 3).

\section{Cichlidogyrus louipaysani / C. kouassii}

The prevalence of $C$. louipaysani was $27.74 \%$ for male fish and $20.74 \%$ for female one. The mean intensity was $2.18 \pm 0.6$ for female and $2.33 \pm 0.6$ for male fish. No significant difference was observed according to host $\operatorname{sex}\left(\mathrm{X}^{2}=2.41\right.$, df $=1, \mathrm{p}=0.12>0.05$; Mann-Whitney p >0.05) (Table 3).

Cichlidogyrus kouassii was present in $6.35 \%$ male host and $3.72 \%$ of female host. The intensities of infestation were $2.36 \pm 1$ in the male and $2.57 \pm 1$ in the female. The prevalence and the intensity of infestation were not significantly different $\left(\mathrm{X}^{2}=1.32\right.$, df $=1, \mathrm{p}=0.25>0.05$; Mann-Whitney $\mathrm{p}>0.05$ ) (Table 3).

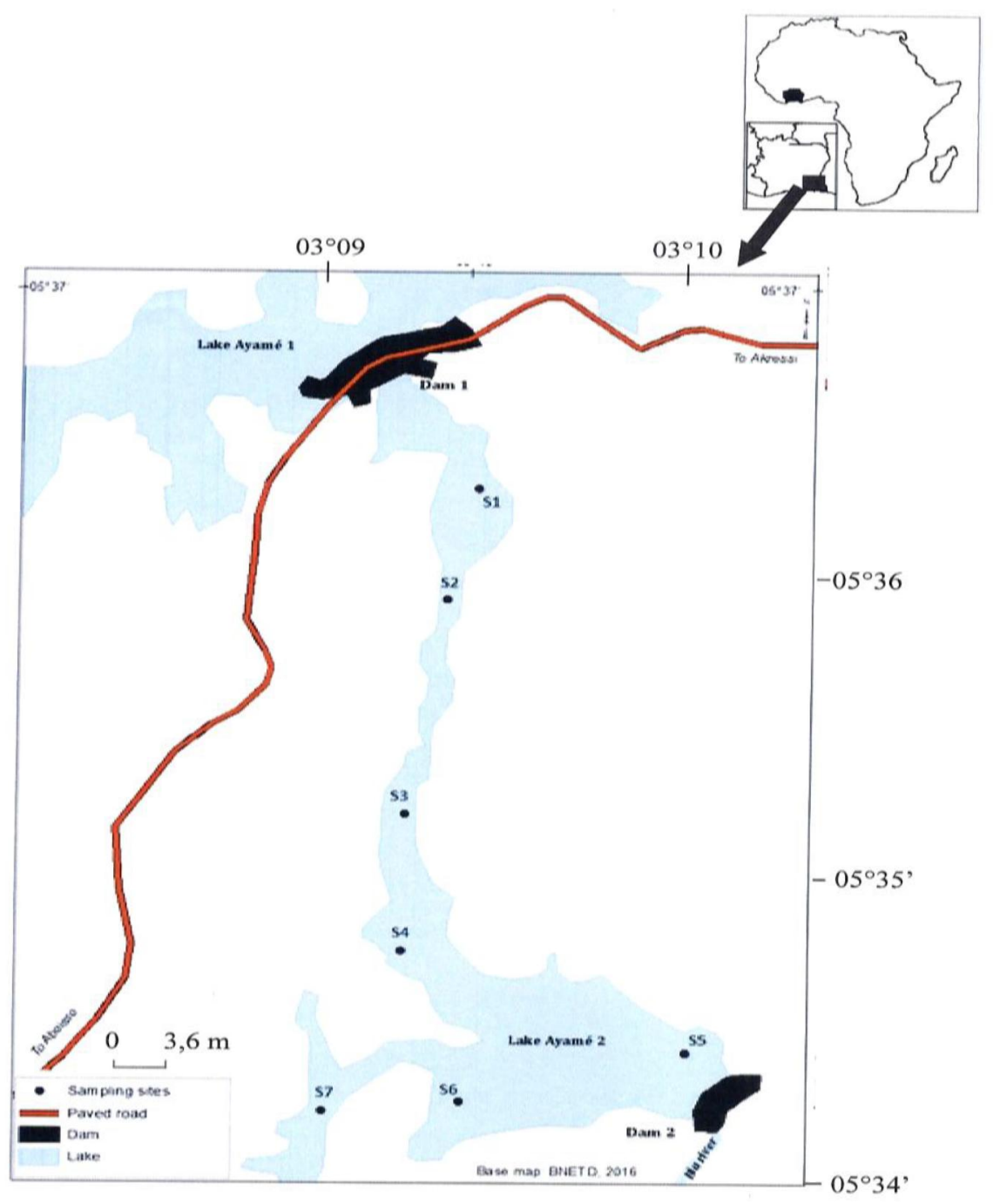

Figure 1: Map of Lake Ayamé 2 (Côte d'Ivoire) showing the sampling sites. 
Y. E. ADOU et al. / Int. J. Biol. Chem. Sci. 11(4): 1559-1576, 2017

Table 1: Prevalence (\%) and mean intensity of Cichlidogyrus species according to season.

\begin{tabular}{|c|c|c|c|c|c|c|c|c|}
\hline Parasites species & Seasons & $\begin{array}{l}\text { Number of } \\
\text { examined fish }\end{array}$ & $\begin{array}{l}\text { Prevalence } \\
\text { (\%) }\end{array}$ & $\begin{array}{l}\text { Mean in } \\
\text { SE }\end{array}$ & ensity \pm & p value & $\begin{array}{c}\text { Comparison } \\
\text { two by two }\end{array}$ & $\begin{array}{c}p \\
\text { value }\end{array}$ \\
\hline \multirow{5}{*}{ C. vexus } & SDS & 50 & 92 & 17.26 & \pm 1.8 & \multirow{5}{*}{$0.02 *$} & SDS-SRS & $0.03 *$ \\
\hline & & & & & & & SDS-LDS & 0.06 \\
\hline & SRS & 52 & 96.15 & 33.28 & \pm 8 & & SDS-LRS & $0.02 *$ \\
\hline & LDS & 120 & 95 & 6.87 & \pm 0.7 & & SRS-LDS & 0.04 \\
\hline & LRS & 139 & 93.53 & 25.68 & \pm 2.1 & & $\begin{array}{l}\text { SRS-LRS } \\
\text { LDS-LRS }\end{array}$ & $\begin{array}{c}0.03 \\
0.01 *\end{array}$ \\
\hline \multirow{6}{*}{ C. ergensis } & SDS & 50 & 80 & 16.98 & \pm 3.9 & \multirow{6}{*}{$0.02 *$} & SDS-SRS & $0.01 *$ \\
\hline & & & & & & & SDS-LDS & 0.06 \\
\hline & SRS & 52 & 88.46 & 20.78 & \pm 7.6 & & SDS-LRS & $0.02 *$ \\
\hline & LDS & 120 & 79.17 & 6.72 & \pm 0.9 & & SRS-LDS & 0.01 * \\
\hline & & & & & & & SRS-LRS & 0.06 \\
\hline & LRS & 139 & 82.73 & 18.87 & \pm 2 & & LDS-LRS & $0.01 *$ \\
\hline \multirow{6}{*}{ C. cubitus } & SDS & 50 & 74 & 10.51 & \pm 1.5 & \multirow{6}{*}{$0.03^{*}$} & SDS-SRS & $0.02 *$ \\
\hline & & & & & & & SDS-LDS & $0.01 *$ \\
\hline & SRS & 52 & 67.31 & 19.54 & \pm 5.2 & & SDS-LRS & 0.01 * \\
\hline & LDS & 120 & 74.17 & 6.56 & \pm 0.6 & & SRS-LDS & $0.02 *$ \\
\hline & & & & & & & SRS-LRS & $0.03 *$ \\
\hline & LRS & 139 & 75.54 & 14.65 & \pm 1.4 & & LDS-LRS & $0.01 *$ \\
\hline \multirow{6}{*}{ C. anthemocolpos } & SDS & 50 & 76 & 6.71 & \pm 2.6 & \multirow{6}{*}{$0.03 *$} & SDS-SRS & $0.01 *$ \\
\hline & & & & & & & SDS-LDS & $0.01 *$ \\
\hline & SRS & 52 & 78.85 & 17.88 & \pm 2.2 & & SDS-LRS & $0.01 *$ \\
\hline & LDS & 120 & 75 & 5.59 & \pm 0.3 & & SRS-LDS & $0.02 *$ \\
\hline & & & & & & & SRS-LRS & 0.06 \\
\hline & LRS & 139 & 65.47 & 15.29 & \pm 2.4 & & LDS-LRS & $0.02 *$ \\
\hline \multirow{6}{*}{ C. arthracanthus } & SDS & 50 & 42 & 5.19 & \pm 0.7 & \multirow{6}{*}{$0.03^{*}$} & SDS-SRS & 0.04 \\
\hline & & & & & & & SDS-LDS & 0.06 \\
\hline & SRS & 52 & 44.23 & 5.61 & \pm 2 & & SDS-LRS & $0.01 *$ \\
\hline & LDS & 120 & 35 & 2.02 & \pm 1 & & SRS-LDS & $0.01 *$ \\
\hline & & & & & & & SRS-LRS & $0.01 *$ \\
\hline & LRS & 139 & 48.20 & 4.31 & \pm 1.5 & & LDS-LRS & $0.01 *$ \\
\hline \multirow[t]{2}{*}{ C. yanni } & \multirow[t]{2}{*}{ SDS } & \multirow[t]{2}{*}{50} & \multirow[t]{2}{*}{0} & \multirow[t]{2}{*}{0} & \multirow[t]{2}{*}{ \pm 0} & \multirow[t]{2}{*}{$0.01 *$} & SDS-SRS & $0.01 *$ \\
\hline & & & & & & & SDS-LDS & $0.01 *$ \\
\hline
\end{tabular}


Y. E. ADOU et al. / Int. J. Biol. Chem. Sci. 11(4): 1559-1576, 2017

\begin{tabular}{|c|c|c|c|c|c|c|c|c|}
\hline & $\begin{array}{l}\text { SRS } \\
\text { LDS } \\
\\
\text { LRS } \\
\end{array}$ & $\begin{array}{c}52 \\
120 \\
\\
139 \\
\end{array}$ & $\begin{array}{c}23.08 \\
4.17 \\
12.23 \\
\end{array}$ & $\begin{array}{c}1.17 \\
2 \\
\\
1.88 \\
\end{array}$ & $\begin{array}{l} \pm 0 \\
\pm 1 \\
\pm 0.8 \\
\end{array}$ & & $\begin{array}{l}\text { SDS-LRS } \\
\text { SRS-LDS } \\
\text { SRS-LRS } \\
\text { LDS-LRS } \\
\end{array}$ & $\begin{array}{c}0.01 * \\
0.01^{*} \\
0.06 \\
0.01 * \\
\end{array}$ \\
\hline C. digitatus & $\begin{array}{l}\text { SDS } \\
\\
\text { SRS } \\
\text { LDS } \\
\\
\text { LRS }\end{array}$ & $\begin{array}{c}50 \\
52 \\
120 \\
\\
139 \\
\end{array}$ & $\begin{array}{c}8 \\
67.31 \\
30.83 \\
76.26 \\
\end{array}$ & $\begin{array}{c}2 \\
\\
3.37 \\
1.43 \\
\\
1.56 \\
\end{array}$ & $\begin{array}{l} \pm 2.4 \\
\pm 1 \\
\pm 1 \\
\pm 0.1\end{array}$ & $0.03 *$ & $\begin{array}{l}\text { SDS-SRS } \\
\text { SDS-LDS } \\
\text { SDS-LRS } \\
\text { SRS-LDS } \\
\text { SRS-LRS } \\
\text { LDS-LRS } \\
\end{array}$ & $\begin{array}{c}0.01^{*} \\
0.03^{*} \\
0.01^{*} \\
0.01^{*} \\
0.06 \\
0.01 *\end{array}$ \\
\hline C. dossoui & $\begin{array}{l}\text { SDS } \\
\\
\text { SRS } \\
\text { LDS } \\
\\
\text { LRS }\end{array}$ & $\begin{array}{c}50 \\
\\
52 \\
120 \\
\\
139\end{array}$ & $\begin{array}{c}4 \\
61.54 \\
37.5 \\
71.22 \\
\end{array}$ & $\begin{array}{l}1.01 \\
\\
3.75 \\
1.84 \\
\\
1.16\end{array}$ & $\begin{array}{l} \pm 0.05 \\
\pm 1 \\
\pm 1 \\
\pm 0.1\end{array}$ & $0.03 *$ & $\begin{array}{l}\text { SDS-SRS } \\
\text { SDS-LDS } \\
\text { SDS-LRS } \\
\text { SRS-LDS } \\
\text { SRS-LRS } \\
\text { LDS-LRS }\end{array}$ & $\begin{array}{c}0.01 * \\
0.07 \\
0.01 * \\
0.01 * \\
0.06 \\
0.01 *\end{array}$ \\
\hline C. lagoonaris & $\begin{array}{l}\text { SDS } \\
\\
\text { SRS } \\
\text { LDS } \\
\\
\text { LRS }\end{array}$ & $\begin{array}{c}50 \\
52 \\
120 \\
\\
139 \\
\end{array}$ & $\begin{array}{c}0 \\
\\
5.77 \\
2.5 \\
11.51 \\
\end{array}$ & $\begin{array}{c}0 \\
3 \\
3.33 \\
2.31 \\
\end{array}$ & $\begin{array}{l} \pm 0 \\
\pm 0 \\
\pm 0.5 \\
\pm 1.2 \\
\end{array}$ & $0.04 *$ & $\begin{array}{l}\text { SDS-SRS } \\
\text { SDS-LDS } \\
\text { SDS-LRS } \\
\text { SRS-LDS } \\
\text { SRS-LRS } \\
\text { LDS-LRS } \\
\end{array}$ & $\begin{array}{c}0.02 * \\
0.02 * \\
0.02 * \\
0.06 \\
0.06 \\
0.06 \\
\end{array}$ \\
\hline C. louipaysani & $\begin{array}{l}\text { SDS } \\
\text { SRS } \\
\text { LDS } \\
\\
\text { LRS }\end{array}$ & $\begin{array}{c}50 \\
52 \\
120 \\
\\
139 \\
\end{array}$ & $\begin{array}{c}4 \\
26.92 \\
23.33 \\
30.94 \\
\end{array}$ & $\begin{array}{l}1.2 \\
2.43 \\
1.29 \\
2.14 \\
\end{array}$ & $\begin{array}{l} \pm 0.1 \\
\pm 0.1 \\
\pm 1 \\
\pm 0.9\end{array}$ & $0.01 *$ & $\begin{array}{l}\text { SDS-SRS } \\
\text { SDS-LDS } \\
\text { SDS-LRS } \\
\text { SRS-LDS } \\
\text { SRS-LRS } \\
\text { LDS-LRS }\end{array}$ & $\begin{array}{c}0.02 * \\
0.06 \\
0.02 * \\
0.02 * \\
0.07 \\
0.01 *\end{array}$ \\
\hline C. kouassii & $\begin{array}{l}\text { SDS } \\
\text { SRS } \\
\text { LDS } \\
\text { LRS }\end{array}$ & $\begin{array}{r}50 \\
52 \\
120 \\
139 \\
\end{array}$ & $\begin{array}{c}0 \\
15.38 \\
2.5 \\
5.04 \\
\end{array}$ & $\begin{array}{c}0 \\
2.13 \\
2 \\
3 \\
\end{array}$ & $\begin{array}{l} \pm 0 \\
\pm 1 \\
\pm 0.1 \\
\pm 1.5\end{array}$ & $0.04 *$ & $\begin{array}{l}\text { SDS-SRS } \\
\text { SDS-LDS } \\
\text { SDS-LRS } \\
\text { SRS-LDS } \\
\text { SRS-LRS } \\
\text { LDS-LRS }\end{array}$ & $\begin{array}{c}0.03 * \\
0.03 * \\
0.03 * \\
\\
0.06 \\
0.07 \\
0.06 \\
\end{array}$ \\
\hline
\end{tabular}


Y. E. ADOU et al. / Int. J. Biol. Chem. Sci. 11(4): 1559-1576, 2017

Table 2: Prevalence (\%) and mean intensity of Cichlidogyrus species according to the size of the host.

\begin{tabular}{|c|c|c|c|c|c|c|c|c|}
\hline $\begin{array}{c}\text { Parasites } \\
\text { species }\end{array}$ & Host length classe & $\begin{array}{c}\begin{array}{c}\text { Number of } \\
\text { examined fish }\end{array} \\
\end{array}$ & Prevalence $(\%)$ & & $\begin{array}{l}\text { an intensity } \\
\pm \mathrm{SE}\end{array}$ & p value & $\begin{array}{c}\text { Comparison } \\
\text { two by two }\end{array}$ & $p$ value \\
\hline \multirow{15}{*}{ C. vexus } & A: $[140-150[$ & 65 & 87.69 & 5.63 & \pm 1.64 & \multirow{15}{*}{$0.01 *$} & A-B & 0.64 \\
\hline & & & & & & & A-C & $0.03 *$ \\
\hline & & & & & & & A-D & $0.03 *$ \\
\hline & & & & & & & A-E & $0.00^{*}$ \\
\hline & B: $[150-160[$ & 63 & 93.65 & 6.93 & \pm 2.77 & & A-F & $0.00^{*}$ \\
\hline & C: $[160-170[$ & 62 & 91.94 & 15.68 & $\begin{array}{l} \pm .28 \\
\pm 3 .\end{array}$ & & B-C & $0.01 *$ \\
\hline & & & & & & & B-D & $0.01 *$ \\
\hline & & & & & & & B-E & $0.01 *$ \\
\hline & & & & & & & B-F & $0.01 *$ \\
\hline & D: $[170-180[$ & 61 & 95.08 & 15.79 & \pm 3.01 & & C-D & 0.7 \\
\hline & \multirow[t]{4}{*}{ E: [180-190[ } & 60 & 100 & 27.65 & $\begin{array}{l} \pm 9.1 \\
\pm 9\end{array}$ & & C-E & $0.03^{*}$ \\
\hline & & & & & & & $\mathrm{C}-\mathrm{F}$ & $0.00^{*}$ \\
\hline & & & & & & & D-E & 0.04 \\
\hline & & & & & & & D-F & $0.02 *$ \\
\hline & $F:[190-200]$ & 50 & 98 & 48.59 & \pm 3 & & E-F & $0.02 *$ \\
\hline \multirow{15}{*}{ C. ergensis } & A: $[140-150[$ & 65 & 58.46 & 7.21 & \pm 3.12 & \multirow{15}{*}{$0.01 *$} & A-B & 0.1 \\
\hline & & & & & & & A-C & 0.06 \\
\hline & & & & & & & A-D & $0.03 *$ \\
\hline & & & & & & & A-E & $0.03 *$ \\
\hline & B: $[150-160[$ & 63 & 65.08 & 10.27 & \pm 0.3 & & A-F & $0.00^{*}$ \\
\hline & C: $[160-170[$ & 62 & 85,48 & 13.62 & \pm 2.9 & & B-C & 0.7 \\
\hline & & & & & & & B-D & 0.2 \\
\hline & & & & & & & B-E & 0.06 \\
\hline & & & & & & & B-F & $0.03 *$ \\
\hline & D: $[170-180[$ & 61 & 91,80 & 16.09 & \pm 2.2 & & C-D & 0.06 \\
\hline & \multirow[t]{4}{*}{ E: [180-190[ } & 60 & 96,67 & 15.76 & \pm 2.5 & & C-E & 0.06 \\
\hline & & & & & & & $\mathrm{C}-\mathrm{F}$ & $0.02 *$ \\
\hline & & & & & & & D-E & 0.07 \\
\hline & & & & & & & D-F & $0.03 *$ \\
\hline & $F:[190-200]$ & 50 & 100 & 24.22 & \pm 5.13 & & E-F & $0.01 *$ \\
\hline \multirow{3}{*}{ C. cubitus } & \multirow[t]{3}{*}{ A: $[140-150[$} & \multirow[t]{3}{*}{65} & 49.23 & 3.28 & \pm 1 & \multirow{3}{*}{$0.00 *$} & A-B & \\
\hline & & & & & & & A-C & $0.03 *$ \\
\hline & & & & & & & A-D & $0.00^{*}$ \\
\hline
\end{tabular}


Y. E. ADOU et al. / Int. J. Biol. Chem. Sci. 11(4): 1559-1576, 2017

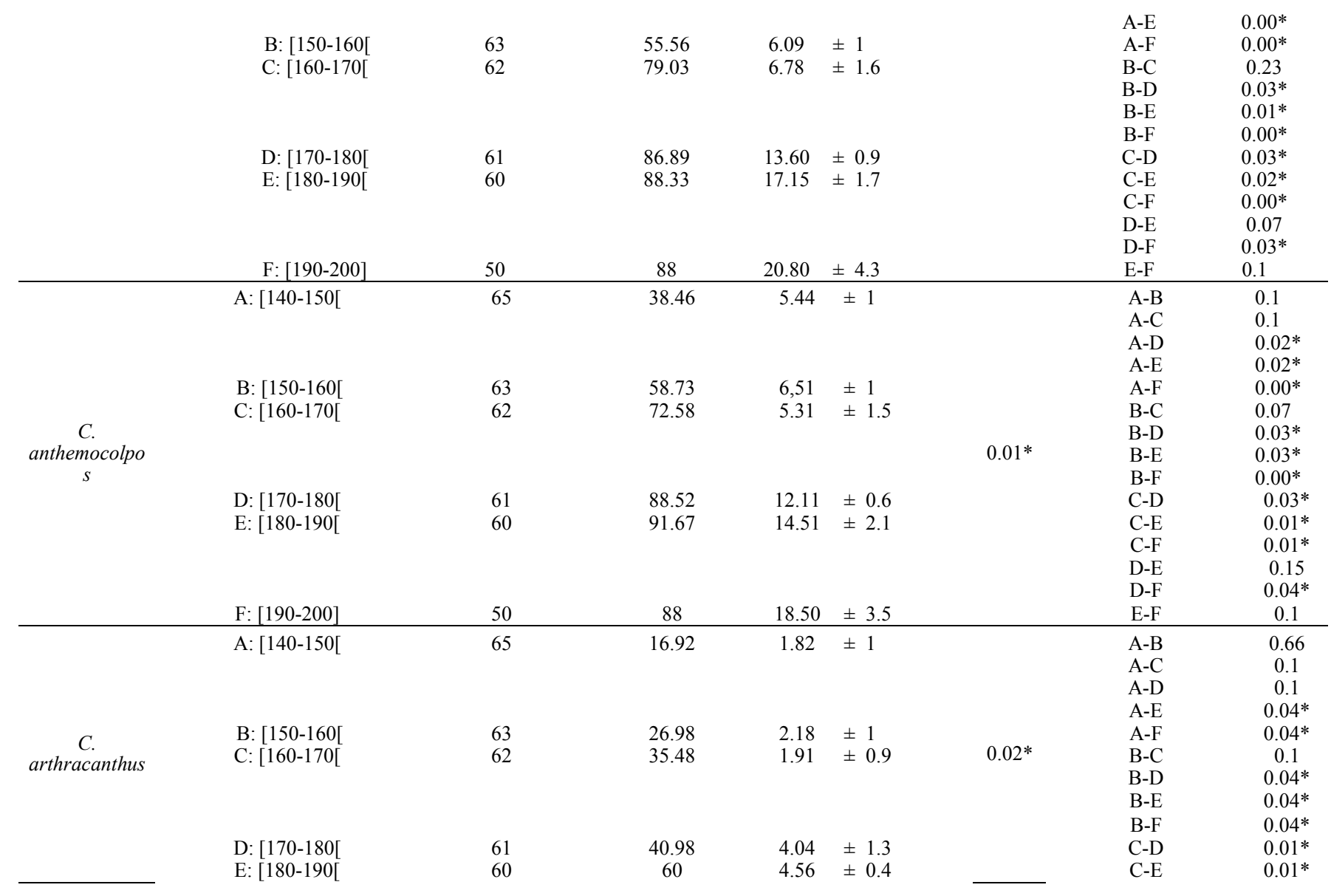


Y. E. ADOU et al. / Int. J. Biol. Chem. Sci. 11(4): 1559-1576, 2017

\begin{tabular}{|c|c|c|c|c|c|c|c|c|}
\hline & & & & & \pm 10 & & $\begin{array}{l}\text { C-F } \\
\text { D-E } \\
\text { D-F } \\
\text { F-F }\end{array}$ & $\begin{array}{c}0.01 * \\
0.6 \\
0.1\end{array}$ \\
\hline & $F:[190-200]$ & 50 & 84 & 5.90 & \pm 1.0 & & E-F & 0.1 \\
\hline \multirow{15}{*}{ C. yanni } & A: [140-150[ & 65 & 1.45 & 2 & \pm 0.01 & \multirow{15}{*}{$0.02 *$} & A-B & $0.00^{*}$ \\
\hline & & & & & & & A-C & $0.01 *$ \\
\hline & & & & & & & A-D & 0.06 \\
\hline & & & & & & & A-E & 0.06 \\
\hline & B: [150-160[ & 63 & 0 & 0 & \pm 0 & & A-F & 0.1 \\
\hline & C: $[160-170[$ & 62 & 1.61 & 1 & \pm 0 & & B-C & $0.01 *$ \\
\hline & & & & & & & B-D & $0.01 *$ \\
\hline & & & & & & & B-E & $0.01 *$ \\
\hline & & & & & & & B-F & $0.01 *$ \\
\hline & D: [170-180[ & 61 & 11.48 & 1.45 & \pm 0.3 & & C-D & 0.06 \\
\hline & E: [180-190[ & 60 & 18.33 & 1.57 & \pm 0.1 & & C-E & 0.06 \\
\hline & & & & & & & C-F & $0.03 *$ \\
\hline & & & & & & & D-E & 0.1 \\
\hline & & & & & & & D-F & 0.1 \\
\hline & F: [190-200] & 50 & 28 & 2.14 & \pm 1.0 & & E-F & 0.2 \\
\hline \multirow{15}{*}{ C. digitatus } & A: [140-150[ & 65 & 27.69 & 1.14 & \pm 0.1 & \multirow{15}{*}{$0.02^{*}$} & A-B & 0.2 \\
\hline & & & & & & & A-C & 0.2 \\
\hline & & & & & & & A-D & 0.1 \\
\hline & & & & & & & A-E & $0.03 *$ \\
\hline & B: $[150-160[$ & 63 & 33.33 & 1.17 & \pm 0.1 & & A-F & $0.03 *$ \\
\hline & C: $[160-170[$ & 62 & 32.26 & 1.77 & \pm 0.3 & & B-C & 0.2 \\
\hline & & & & & & & B-D & 0.06 \\
\hline & & & & & & & B-E & $0.03 *$ \\
\hline & & & & & & & B-F & $0.03 *$ \\
\hline & D: [170-180[ & 61 & 63.93 & 1.85 & \pm 0.01 & & C-D & 0.06 \\
\hline & E: [180-190[ & 60 & 66.67 & 2.23 & \pm 0.1 & & C-E & 0.07 \\
\hline & & & & & & & C-F & 0.06 \\
\hline & & & & & & & D-E & 0.06 \\
\hline & & & & & & & D-F & $0.04 *$ \\
\hline & F: [190-200] & 50 & 88 & 2,90 & \pm 0.6 & & E-F & 0.1 \\
\hline \multirow{3}{*}{ C. dossoui } & A: [140-150[ & 65 & 15.38 & 1.21 & \pm 0.7 & \multirow{3}{*}{$0.02^{*}$} & A-B & 0.1 \\
\hline & & & & & & & A-C & 0.1 \\
\hline & & & & & & & A-D & $0.04 *$ \\
\hline
\end{tabular}


Y. E. ADOU et al. / Int. J. Biol. Chem. Sci. 11(4): 1559-1576, 2017

\begin{tabular}{|c|c|c|c|c|c|c|c|c|}
\hline & & & & & & & A-E & $0.03^{*}$ \\
\hline & B: $[150-160[$ & 63 & 23.81 & 1.38 & \pm 0.5 & & $A-F$ & $0.02^{*}$ \\
\hline & C: $[160-170[$ & 62 & 37.10 & 1.96 & \pm 1.2 & & B-C & 0.1 \\
\hline & & & & & & & B-D & $0.04 *$ \\
\hline & & & & & & & B-E & $0.04 *$ \\
\hline & & & & & & & B-F & $0.04^{*}$ \\
\hline & D: [170-180[ & 61 & 68.85 & 2.22 & \pm 0.6 & & C-D & 0.1 \\
\hline & E: [180-190[ & 60 & 70 & 2.87 & \pm 0.2 & & C-E & 0.1 \\
\hline & & & & & & & C-F & $0.0 .4^{*}$ \\
\hline & & & & & & & D-E & 0.1 \\
\hline & & & & & & & D-F & 0.06 \\
\hline & F: [190-200] & 50 & 92 & 3.10 & \pm 0.2 & & E-F & 0.06 \\
\hline \multirow{15}{*}{ C. lagoonaris } & A: [140-150[ & 65 & 0 & 0 & \pm 0 & \multirow{15}{*}{$0.00^{*}$} & A-B & 0 \\
\hline & & & & & & & A-C & $0.00^{*}$ \\
\hline & & & & & & & A-D & $0.00^{*}$ \\
\hline & & & & & & & A-E & $0.00^{*}$ \\
\hline & B: $[150-160[$ & 63 & 0 & 0 & \pm 0 & & A-F & 0.00 * \\
\hline & C: $[160-170[$ & 62 & 1.61 & 2 & \pm 0.6 & & B-C & $0.00^{*}$ \\
\hline & & & & & & & B-D & $0.00^{*}$ \\
\hline & & & & & & & B-E & $0.00^{*}$ \\
\hline & & & & & & & B-F & $0.00^{*}$ \\
\hline & D: [170-180[ & 61 & 8.20 & 2.33 & \pm 1.4 & & C-D & 0.1 \\
\hline & E: [180-190[ & 60 & 11.67 & 2.6 & \pm 1.7 & & C-E & 0.1 \\
\hline & & & & & & & C-F & 0.1 \\
\hline & & & & & & & D-E & 0.1 \\
\hline & & & & & & & D-F & 0.1 \\
\hline & F: [190-200] & 50 & 18 & 2.86 & \pm 1.6 & & E-F & 0.1 \\
\hline \multirow{12}{*}{ C. louipaysani } & A: $[140-150[$ & 65 & 0 & 0 & \pm 0 & \multirow{12}{*}{$0.02 *$} & A-B & $0.00 *$ \\
\hline & & & & & & & A-C & $0.00^{*}$ \\
\hline & & & & & & & A-D & $0.00^{*}$ \\
\hline & & & & & & & A-E & $0.00^{*}$ \\
\hline & B: $[150-160[$ & 63 & 19.05 & 1.42 & \pm 0.3 & & A-F & $0.00^{*}$ \\
\hline & C: $[160-170[$ & 62 & 22.58 & 1.65 & \pm 0.9 & & B-C & $0.04 *$ \\
\hline & & & & & & & B-D & $0.04 *$ \\
\hline & & & & & & & B-E & 0.1 \\
\hline & & & & & & & B-F & 0.1 \\
\hline & D: [170-180[ & 61 & 27.87 & 2.07 & \pm 1.0 & & C-D & 0.1 \\
\hline & E: [180-190[ & 60 & 38.33 & 2.12 & \pm 0.4 & & C-E & 0.1 \\
\hline & & & & & & & C-F & 0.1 \\
\hline
\end{tabular}

1571 
Y. E. ADOU et al. / Int. J. Biol. Chem. Sci. 11(4): 1559-1576, 2017

\begin{tabular}{|c|c|c|c|c|c|c|c|c|}
\hline & F: [190-200] & 50 & 42 & 2.33 & \pm 0.8 & & $\begin{array}{l}\text { D-E } \\
\text { D-F } \\
\text { E-F }\end{array}$ & $\begin{array}{l}0.1 \\
0.1 \\
0.1\end{array}$ \\
\hline \multirow{15}{*}{ C. kouassii } & A: $[140-150[$ & 65 & 3.08 & 2 & \pm 0.4 & \multirow{15}{*}{0.1} & A-B & 0.1 \\
\hline & & & & & & & $\mathrm{A}-\mathrm{C}$ & 0.1 \\
\hline & & & & & & & A-D & 0.1 \\
\hline & & & & & & & A-E & 0.1 \\
\hline & B: $[150-160[$ & 63 & 1.59 & 2 & \pm 0.1 & & A-F & 0.1 \\
\hline & C: $[160-170[$ & 62 & 4.84 & 2.25 & \pm 1.2 & & $\mathrm{~B}-\mathrm{C}$ & 0.1 \\
\hline & & & & & & & B-D & 0.1 \\
\hline & & & & & & & B-E & 0.1 \\
\hline & & & & & & & B-F & 0.1 \\
\hline & D: $[170-180[$ & 61 & 4.92 & 2.33 & \pm 1.3 & & C-D & 0.1 \\
\hline & \multirow[t]{4}{*}{ E: [180-190[ } & 60 & 6.67 & 2.4 & \pm 1.3 & & $C-E$ & 0.1 \\
\hline & & & & & & & $\mathrm{C}-\mathrm{F}$ & 0.1 \\
\hline & & & & & & & D-E & 0.1 \\
\hline & & & & & & & D-F & 0.1 \\
\hline & $\mathrm{F}:[190-200]$ & 50 & 10 & 2.67 & \pm 1.4 & & E-F & 0.1 \\
\hline
\end{tabular}

$*$ Significant level at $p<0.05 ; \mathrm{SE}=$ Standard Error; $\mathrm{C}=$ Cichlidogyrus

Table 3: Prevalence (\%) and mean intensity of Cichlidogyrus species according to the sex of the host.

\begin{tabular}{|c|c|c|c|c|}
\hline \multirow{3}{*}{$\begin{array}{l}\text { sex } \\
\text { Number of examined fish } \\
\text { Parasites species }\end{array}$} & \multirow{2}{*}{\multicolumn{2}{|c|}{$\begin{array}{c}\text { Male } \\
173\end{array}$}} & \multirow{2}{*}{\multicolumn{2}{|c|}{$\begin{array}{c}\text { Female } \\
188\end{array}$}} \\
\hline & & & & \\
\hline & Prevalence (\%) & $\begin{array}{l}\text { Mean intensity } \\
\quad \pm \text { SE }\end{array}$ & Prevalence (\%) & $\begin{array}{c}\text { Mean intensity } \\
\pm \mathrm{SE}\end{array}$ \\
\hline C. vexus & 90.17 & $13.32 \pm 1.61$ & 97.87 & $24.47 \pm 2.7$ \\
\hline C. ergensis & 81.50 & $9.14 \pm 0.2$ & 82.45 & $20.35 \pm 0.1$ \\
\hline C. cubitus & 71.10 & $9.53 \pm 0.9$ & 76.06 & $14.15 \pm 2.5$ \\
\hline C. anthemocolpos & 70.52 & $10.98 \pm 0.6$ & 73.40 & $11.18 \pm 1$ \\
\hline C. arthracanthus & 45.09 & $4.10 \pm 0.5$ & 39.89 & $3.89 \pm 0.6$ \\
\hline C. dossoui & 52.60 & $2.51 \pm 1.9$ & 46.28 & $1.17 \pm 0.03$ \\
\hline C. digitatus & 54.34 & $2.65 \pm 0.8$ & 46.81 & $1.08 \pm 0.1$ \\
\hline C. louipaysani & 27.75 & $2.19 \pm 0.4$ & 20.74 & $2.33 \pm 0.6$ \\
\hline C. yanni & 6.94 & $1.75 \pm 0.01$ & 11.70 & $1.59 \pm 0.02$ \\
\hline C. lagoonaris & 5.20 & $2.11 \pm 0.5$ & 6.91 & $2.85 \pm 1.6$ \\
\hline C. kouassii & 6.36 & $2.36 \pm 1$ & 3.72 & $2.57 \pm 1$ \\
\hline
\end{tabular}

$\mathrm{SE}=$ Standard Error $; \mathrm{C}=$ Cichlidogyrus 


\section{DISCUSSION}

In this study, eleven parasite species belonging to genus Cichlidogyrus were recorded on the gills of Tilapia guineensis from man-made Lake Ayamé 2. The polyparasitism observed in this study has also been reported by various authors in mouthbreeder tilapias. Pariselle and Euzet (2009) reported nineteen monogenean species infested the same fish gill system. The gills of Tilapia zillii harboured eight monogenean species (Ibrahim, 2012). Also, it appears from the work of Blahoua et al. (2016) that six monogenean species colonized the gills of Oreochromis niloticus from man-made Lake Ayamé 1. This colonization of T. guineensis by several congeneric species could be explained by the permanent presence of vacant niches on its gill biotope. In fact, according to Buchmann and LindenstrØm (2002) and Simkova et al. (2006), in the natural environment, the parasitic load is generally weak and therefore, the niches are always available on the gill biotope, facilitating the simultaneous colonization of the same host by several species of monogeneans.

All the species of monogeneans identified have been present throughout the year in the host, except for Cichlidogyrus lagoonaris, C. kouassii and C. yanni which were absent in small dry season. A definite seasonal effect was noted for all monogenean infracommunities under investigation. The highest prevalence and mean intensity of infection were observed in rainy seasons (long and small rainy seasons) and the lowest ones in dry seasons (long and small dry seasons). Our results coincide with those of Blahoua et al. $(2015$, 2016) who pointed out that monogenean parasites on the gills of Tilapia zillii and Oreochromis niloticus respectively, showed higher prevalence and intensity of infection in the long rainy season and lower rate of infection in long dry season. Similarly, Bilong Bilong and Tombi (2005) had reported that Dactylogyrus insolitus and D. bopeleti appeared to be more prevalent and more abundant in the rainy seasons on the gills of
Barbus martorelli. They explained this by the fact the dry seasons were characterized by the mortality of adult worms due to of higher water temperature. In fact, temperature is recognized as an important factor in controlling the occurrence of monogeneans but different species appear to react in different ways (Modu et al., 2014). However, it is evident from other fields studies (Keremah and Inko-Tariah, 2013; Modu et al., 2014) that temperature is not the only factor influencing the proliferation of monogenean biomass, other abiotic factors such as $\mathrm{pH}$, dissolved oxygen, ammonia, concentration of suspended solids, conductivity, water transparency) might mask the effect of temperature. As thought by the authors mentioned above our results could be due to the effect of these factors.

It has been observed that for the majority representatives of the studied component infracommunity, specific parasitic load increased with the host size. Various authors have found positive correlations between parasitic load and host size. Tombi et al. (2014) reported that the highest mean intensity of Dactylogyrus amieti and Dogielius njinei were observed in larger fish (LS $>7.5 \mathrm{~cm}$ ) compared with other groups. Blahoua et al. (2016) found that specimens of Oreochromis niloticus whose standard length varied between 100 and $250 \mathrm{~mm}$ harbored more monogeneans than those whose Standard length was between 50 and $100 \mathrm{~mm}$. This observation can be due to the fact that, larger fish had more time to accumulate parasites than younger ones (Ibrahim, 2012). According to Tekin-Özan et al. (2008), larger fish offer large colonized surfaces area to parasites. In fact, the gill filaments are the supporting organs on which monogeneans are attached, their growth with size of Tilapia guineensis would increase the colonizing gill surface, which would justify the growth of parasitism with the size of this host. Furthermore, the volume of water that passes through the gills of larger fish is more important and thus conveys more oncomiracidium (Simkova et al., 2006). 
Conversely, we pointed out no correlation between the parasitic intensities of Cichlidogyrus kouassii with the size of Tilapia guineensis. These observations corroborate those of Turgut et al. (2012) who showed that the size of Cyprinids had no influence on the occurrence of its monogenean gill parasites. Our results can be explained by the production of the chemical stimuli (mucus) by big fishes. In fact, one or more components of this mucus which permits the infective stages of Cichlidogyrus kouassii to identify host species would interfere with reproductive functions of big host fishes. This result would be a weak attractiveness to the infective stages by big hosts.

In Tilapia guineensis, Cichlidogyrus lagoonaris, C. louipaysani and of C. kouassii showed no preference for host sex. This observation agrees with the findings of Tombi et al. (2014) who found no difference in infection of $C$. thurstonae, $C$. halli and $C$. tilapiae attributable to the sex of Oreochromis niloticus. Similar observations were made by other researcher such as Blahoua et al. (2015). This result suggests that very few parasites species have a preference in relation to the sex of the host (Rohde, 1993). However, females $T$. guineensis were heavily infested by Cichlidogyrus vexus, C. ergensis, C. cubitus and C. anthelmocolpos. Ibrahim (2012) also showed that the prevalence and mean infection intensity of Cichlidogyrus arthracanthus, C. aegypticus, C. tiberianus and $C$. tilapiae were higher in the female host fishes than in the male ones. The highest prevalence and mean intensity of female fishes may be related to investment in reproduction of female fishes is more costly than that in males ones, thus females are more susceptible to parasite infection in periods of investment in gonad developpement (Simkova et al., 2005; Ibrahim, 2012). These results also may be attributed to the immune response of the host due to in the endocrine glands activities between the male and the female host fishes which have been suggested by Ibrahim and Soliman (2011). Furthermore, males Tilapia guineensis were more infested by Cichlidogyrus arthracanthus, C. yanni, C. digitatus and C. dossoui. Aloo et al. (2004) had also reported that males tended to harbor more parasites than females in many freshwater fish species. Our results could be due to the combination of several factors including host's diet as reported Siddiqui et al. (2014).

\section{ACKNOWLEDGEMENTS}

The authors are grateful to the staff of Hydrobiology Laboratory of the Félix Houphouët Boigny University (Côte d'Ivoire) for fieldwork assistance, the fishers and the local population of Ayamé.

\section{REFERENCES}

Akinrotimi, OA. 2006. Effects of acclimation on haematoligical characteristics of black-chin tilapia. Post Graduate Diploma Project, Department of Fisheries, Rivers State University of Science and Technology, Port Harcourt. p. 65.

Akinwumi FO. 2003. Food and feeding habits of Tilapia zillii (Pisces: Cichlidae) in Ondo State University Fish Farm. The 16th Annual Conference of FISON, 4-9 November 2001, Maiduguri, Nigeria. pp195-198.

http://aquaticcommons.org/3618/1/16P1 95.pdf

Aloo PA. 2002. A comparative study of helminth parasites from the fish Tilapia zillii and Oreochromis leucostictus in lake Naivasha and Oloidien bay, Kenya. J. Helminthol., 76: 95-102.

Aloo PA, Anam RO, Mwangi JN. 2004. Metazoan Parasites of Some Commercially Important Fish along the Kenyan Coast. Western Indian Ocean. $J$. Mar. Sci., 3(1): 71-78.

Baidoo K, Abobi SM, Agbeko E. 2015. Ectoparasites Infestation of Nile Tilapia (Oreochromis niloticus) in Concrete Ponds in Tamale, Ghana. Int. J. Aquacult., 5(4): $1-5 . \quad$ doi: 10.5376/ija.2015.05.0004 
Bilong Bilong CF, Njiné T. 1998. Dynamique de populations de trois monogènes parasites d'Hemichromis fasciatus (Peters) dans le lac municipal de Yaoundé et intérêt possible en pisciculture intensive. Sci. Nat. Vie, 34: 295-303

Bilong Bilong CF, Tombi J. 2005. Temporal structure of a component community gill parasites of Barbus martorelli (Roman) (freshwater Cyprinidae) in the Centre province, Cameroon. Cam. J. Biochem. Sci., 13: 9-18.

Blahoua KG, Yao SS, Etilé RN, N'Douba V. 2015. Infection dynamics of four gill Monogenean species from Tilapia zillii (Gervais, 1848) in man-made Lake Ayame I, Côte d'Ivoire, Int. J. Biol. Chem. Sci., 9(1): 12-23.

Blahoua KG, Yao SS, Etilé RN, N'Douba V. 2016. Distribution of gill monogenean parasites from Oreochromis niloticus (Linné, 1758) in man-made Lake Ayamé I, Côte d'Ivoire. Afri. J. Agri. Res., 11(2): 117-129.

Buchmann K, LindenstrØm T. 2002. Interactions between monogenean parasites and their fish hosts. Int. J. Parasitol., 32: 309-319.

Bush AO, Kevin DL, Jeffrey ML, Allen WS. 1997. Parasitology meets ecology on its own terms. J. Parasitol., 83: 575-583.

El-Sayed A-FM. 2006. Tilapia culture. CABI, Oxford Ergens R. 1981. Nine species of the genus Cichlidogyrus Paperna, 1969 (Monogenea: Ancyrocephalinae) from Egyptian fishes. Folia Parasitol., 28: 205-214.

Ibrahim MM, Soliman MF. 2011. Prevalence and site preferences of heterophyid metacercariae in Tilapia zillii from Ismalia fresh water canal, Egypt. Parasite, 17: 233-239.

Ibrahim, M.M. (2012). Variation in parasite infracommunies of Tilapia zillii in relation to some biotic and abiotic factors. Int. J. Zool. Res., 8(2): 59-70.

Keremah RI, Inko-Tariah MB. 2013. Comparative study of ectoparasites on
Nile tilapia (Oreochromis niloticus) cultured under integrated and unintegrated pond systems. Afr. J. Biotechnol., 12(19): 2711-2714.

Lom J, Dykova I. 1992. Protozoan parasites of fishes. Elsevier, Amsterdam, London, New York, Tokyo.

Malmberg G. 1957. On the occurrence of Gyrodactylus on Swedish fishes. In: Swedish, with description of species and a summary in English. Skrifterutgivna av Sodra Sveriges Fiskeriforening, p.19-76.

Modu BM, Zaleha K, Shaharom-Harrison FM. 2014. Water Quality Assessment using Monogenean Gill Parasites of Fish in Kenyir Lake, Malaysia. Nig. J. Fish. Aqua., 2(1): 37-47.

Pariselle A, Euzet L. 1998. Five new species of Cichlidogyrus (Monogenea: Ancyrocephalidae) from Tilapia brevimanus, $T$. buttikoferi and $T$. cessiana from Guinea, Ivory Coast and Sierra Leone (West Africa). Folia Parasitol., 45: 275-282.

Pariselle A, Euzet L. 2009. Systematic revision of dactylogyridean parasites (Monogenea) from cichlid fishes in Africa, the Levant and Madagascar. Zoosystema, 31(4): 849-898.

Philippart JCL, Ruwet JCL .1982. Ecology and distribution of tilapias. In: Pullin RSV, Lowe-McConnell RH (eds) The biology and culture of tilapias. International Center for Living Aquatic Resources Management (ICRAM) conference proceedings, 7: 15-59.

Rohde K. 1993. Ecology of marine parasites. An introduction to marine parasitology, 2nd Ed. Cab International, Wallingford, Oxon 298p.

Siddiqui S, Matera C, Radakovic ZS, Hasan MS, Gutbrod P, Rozanska E, Sobczak M, Torres MA, Grundler FM. 2014. Parasitic worms stimulate host NADPH oxidases to produce reactive oxygen species that limit plant cell death and promote infection. Sci. Signal., 7(320):ra33. doi: 10.1126/scisignal. 2004777. 
Simkova A, Jarkovsky J, Koubcova B, Barus V, Prokes M. 2005. Association between fish reproductive cycle and the dynamique of Metazoan parasite infection. Parasitol. Res., 95: 65-72.

Simkova A, Verneau O, Gelnar, M, Morand S. 2006. Specificity and specialization of congeneric Monogeneans parasiting Cyprinid. Evolution, 60: 1023-1037. http://dx.doi.org/10.1554/05-521.1.

Sures B, Streit B. 2001. Eel parasite diversity and intermediate host abundance in the River Rhine, Germany. Parasitology, 123: 185191.

Tammy W. 2002. Fish oil may help your heart. Available at www.encyclopedia.com/doc/ 1P1$51943312 \quad \mathrm{htm}$ $<$ http://www.encyclopedia.com/doc/1P1$51943312 \mathrm{htm}>$.

Tekin-Özan S, Kir İ, Barlas M. 2008. Helminth Parasites of Common Carp (Cyprinus carpio L., 1758) in Beyşehir Lake and Population Dynamics Related to Month and Host Size. Turk. J. Fish. Aquat. Sci., 8: 201-205.

Teugels GG, Thys van den Audenaerde DFE. 2003. Cichlidae. In: Lévêque C, Paugy D, Teugels GG, eds. Faune des poissons d'eaux douces et saumâtres de l'Afrique de l'Ouest, Tome 2. Musée Royal d'Afrique Centrale (Tervuren), ORSTOM (Paris), p. 521-600.
Toko II, Attakpa EY, Elegbe H. 2010. Performances biologiques, zootechniques et nutritionnelles de Tilapia guineensis en milieux naturel et d'élevage. Int. J. Biol. Chem. Sci., 4(5): 1629-1640.

Tombi J, Akoumba JF, Bilong Bilong CF. 2014. The monogenean community on the gills of Oreochromis niloticus from Melen fish station in Yaounde, Cameroon. Int. J. Mod. Biol. Res., 2: 1623.

Turgut EN, Develi N, Özgül G. 2012. Occurrence of Dactylogyrus species (Plathelminths, Monogenean) on Cyprinids in Almus Dam Lake, Turkey. Turk. J. Fish Aquat. Sci., 12: 15-21.

Valtonen ET, Holmes JC, Koskivaara M. 1997. Eutrophication, pollution and fragmentation: effects on parasite communities in roach (Rutilus rutilus) and perch (Perca fluviatilis) in four lakes in the Central Finland. Can. J. Aquat. Sci., 54: 572-585.

Wang M, Lu M. 2015. Tilapia polyculture: a global review. Aquac. Res. doi:10.1111/are.12708.

Whittington ID, Cribb BW, Hamwood TE, Halliday JA. 2000. Host-specificity of monogenean (Platyhelminth) parasites: a role for anterior adhesive areas. Int. $J$. Parasitol., 30: 305-320. 